\title{
Correction to: Psychiatric symptoms, risk, and protective factors among university students in quarantine during the COVID- 19 pandemic in China
}

\author{
Shufang Sun ${ }^{1,2}$, Simon B. Goldberg ${ }^{3}$, Danhua Lin ${ }^{4^{*}}$, Shan Qiao ${ }^{5}$ and Don Operario ${ }^{1,2}$
}

\section{Correction to: Global Health 17, 15 (2021) \\ https://doi.org/10.1186/s12992-021-00663-x}

Following publication of the original article [1], it was brought to our attention that the article had been provided with incorrect affiliation details.

The affiliation details have been updated in the original article and the correct details can be seen in this correction.

The authors apologize for any inconvenience caused.

\section{Author details}

${ }^{1}$ Department of Behavioral and Social Sciences, Brown University School of Public Health, Providence, RI, USA. ${ }^{2}$ Mindfulness Center at Brown University, Providence, RI, USA. ${ }^{3}$ Department of Counseling Psychology, University of Wisconsin-Madison College of Education, Madison, WI, USA. Institute of Developmental Psychology, Beijing Normal University, Beijing, China. ${ }^{5}$ Department of Health Promotion, Education, and Behavior, University of South Carolina Arnold School of Public Health, Columbia, SC, USA.

Published online: 26 April 2021

\section{Reference}

1. Sun S, Goldberg SB, Lin D, Qiao S, Operario D. Psychiatric symptoms, risk, and protective factors among university students in quarantine during the COVID-19 pandemic in China. Glob Health. 2021). https://doi.org/10.1186/ s12992-021-00663-x;17(1):15.

The original article can be found online at https://doi.org/10.1186/s12992021-00663-x

* Correspondence: danhualin@bnu.edu.cn

${ }^{4}$ Institute of Developmental Psychology, Beijing Normal University, Beijing, China

Full list of author information is available at the end of the article

(c) The Author(s). 2021 Open Access This article is licensed under a Creative Commons Attribution 4.0 International License, which permits use, sharing, adaptation, distribution and reproduction in any medium or format, as long as you give appropriate credit to the original author(s) and the source, provide a link to the Creative Commons licence, and indicate if changes were made. The images or other third party material in this article are included in the article's Creative Commons licence, unless indicated otherwise in a credit line to the material. If material is not included in the article's Creative Commons licence and your intended use is not permitted by statutory regulation or exceeds the permitted use, you will need to obtain permission directly from the copyright holder. To view a copy of this licence, visit http://creativecommons.org/licenses/by/4.0/ The Creative Commons Public Domain Dedication waiver (http://creativecommons.org/publicdomain/zero/1.0/) applies to the data made available in this article, unless otherwise stated in a credit line to the data. 